\title{
Punk Community in Criminology Study (Study in Ngaliyan District, Semarang City)
}

\author{
Nurul Izzah Millenia ${ }^{1}$, Yuni Anan², Indah Lestari³, Ridwan Arifin4, Ashbar Hidayat ${ }^{5}$ \\ 1, 2, Independent Researcher on Law, Crimes, and Society Forum, Semarang, Indonesia \\ ${ }^{3,5}$ Independent Researcher on Community and Crimes \\ ${ }^{4}$ Faculty of Law, Universitas Negeri Semarang, Indonesia \\ @ nurul_izzah@gmail.com
}

\begin{abstract}
The purpose of this research is to find out what criminal cases were carried out by punk children, then what factors behind them committed the crime, and why they could enter the punk community. Punk kids are always associated with a negative action, look weird, steal, children are slang, immoral, and other negative things. Sometimes punk children choose to live on the road not only a factor in the conditions of economic difficulties, but also because they enjoy environmental conditions on the road, they feel their families do not care, and lack of education. The research method used in conducting research on the criminal acts of punk children community is to use qualitative research methods with a sociological juridical approach. Qualitative research methods according to Lexy J Moleong are research that intends to understand the phenomenon of what is understood by the subject of research, such as behavior, perceptions, motivations, actions, etc., holistically and in description in the form of words and language in a natural context Data collection uses quantitative methods. The results of the study concluded that criminal acts or crimes by punk children were carried out due to economic, family, environmental factors, and lack of education.
\end{abstract}

Keywords: Crime, Punk, Community, Deviance Factor

\section{Introduction}

Criminology comes from the Latin crimen; and Greece, which refers to scientific studies of the nature, extent, causes, and control of criminal behavior both in individuals and in cultural, social, and political, and economic life (Utari, 2012; Juliana \& Arifin, 2019). The scope of criminology covers three main things, namely the process of making criminal law, and criminal procedure, criminal etiology, which discusses theories that cause crime, reactions to violations of the law. Criminology is closely related to crime and even criminology discusses crime, and perpetrators of crime.

Crime itself has the meaning of an act that violates legal norms (criminal law), adverse behavior, behavior that causes victims. according to criminology in Indonesia, crime is seen as behavior that has been decided by the court, behavior that needs to be criminalized, population of detained perpetrators, acts that violate the norms, actions that get social reactions.

According to Moeljatno, crime in Dutch is called misdrijven, which means an act that is despicable and related to the law, meaning that it is nothing other than breaking the law "Regarding the definition" of crime is part of an act against the law 
or offense (Moeljatno, 1993). In a crime case there must be a perpetrator and a victim. the perpetrators according to the criminal law code formulated in article 55 paragraph (1) are "convicted as perpetrators of a criminal offense: those who commit, who order to do, who take part in committing, and those who deliberately encourage others to commit acts (Moeljatno, 2011; Arifin, 2020; Muhtada \& Arifin, 2018). the causative factor for the existence of a crime could be due to family, economic, social, and political factors. Perpetrators can also be individuals or groups. One group that is often considered by the public to commit a crime is the punk group. Why is that punk group considered a group that likes to riot and commit crimes? Is it because their clothes are randomly scrambled and like to roam the streets.

Punk was born in the United Kingdom, punk is a form of disappointment of young British people to the situation and political conditions during the 1970s. They come from working class youths, such as workers who feel disappointed with the moral decline of the government and the mainstream cultural community and also the prolonged economic slump. The ideology carried by the punker is anti-establishment where they want to live independently, and do not depend on the capitalist culture that is carried by the upper classes (Al Ramadhan, 2016). The ideology adopted represents a protest against social inequality, the context of anarchism which is understood is the nature of violence is always attached to punk and punkers so that they are always constructed as a negative community. The negative construction creates stereotypes which then marginalize punkers so that they often experience rejection in social life.

The rejection that they often experience because of their lifestyles and mindset that is considered unusual by the mainstream groups finally punker made an ethic of living that is, DIY (Do-it-yourself). DIY emphasized that punker does not need anyone to survive. But punk ideology quickly spread by using DIY ethics. Their style of dress is also a way to confirm their identity ( $\mathrm{Al}$ Ramadhan, 2016).

Formation of punk culture is influenced by and manifested in four main elements, namely music, fashion, community and thought. The punk movement is often seen as a youth culture based on the anxiety of teenagers. However, punk as a subcularization is far more advanced than rebellion and fashion because punk generally seeks a lifestyle that is different from the norms of society. The punk aspect is one of the most important factors that triggers an independent subculture. DIY ideology was the one who kept the punk subculture alive from 1970 to the present (Moran, 2010). In the life of the punk community a lot of things are obtained according to the members, especially freedom of expression. This freedom of expression is in the form of freedom of dress, freedom of association, freedom of lifestyle and so on.

Punk continues to grow throughout the world, including to Indonesia. Punk first appeared in Indonesia in big cities like Jakarta, Bandung, Yogyakarta and Bali. According to Fathun (2009) in his essay the spread and formation of punk culture in Indonesia is divided into four major periods. The first period was pre-punk in Indonesia which occurred in the late 1980s. The birth of cultural groups such as punk culture brought four elements, namely: music, fashion, hangouts and thought (Thompson, 2004).

The career has divided the punk period into several periods, namely the pre-Jakarta punk period in 1980 (research centered on Jakarta), the period of the birth of the first punk $1989 / 1990$ to 1995 , the second period of punk from 1996 to 2001, and the period of Indonesian punk go international from 2001 to with 2006. (Karib, 2009; Al Ramadhan, 2016).

Pre punk period of Jakarta in 1980 the condition of the musical journey at that time was marked by the booming trash metal music stream among young people at that time. This is evidenced by the presence of bands that stole the flow of trash metal, including sucker heads, Pinthfull death, and rotors. At the center of the tornado, the music at that time in Putrano's opinion in Karib (2009) was Pid Pub. At that moment the existence of the punk in Jakarta had not yet been smelled. However, the unwitting pub also became the forerunner of the punk community in Indonesia because some trash metal fans would later become the pioneers of the formation of punk groups. The meeting of one of the pioneers named Beri and Acid who later gave birth to the punk generation was pronounced. The appearance of the pioneers was easily detected because of his style of dress, and hair style.

The period of the birth of the first punk $1989 / 1990$ to 1985 the presence of the first punk generation could not be separated from bands such as Anti-Septic, Young Offender, South Sex, and South Primitiv. The appearance of these punk kids with unique physical identities or appearances is not yet acceptable. Not infrequently there are often 
fights between punk kids and community groups that occur because of misunderstandings. Because they were not accepted by the community, they decided to create their own exclusive group. The first generation did not make their own cultural fences they tried to use technology even though it was not as sophisticated as now. In 1994 one band experienced a decline in existence due to many things one of them because many members overdosed due to drugs, after that several other members left and made their own band.

The second period of punk from 1996 to 2001 after the dissolution of the YO band and made the punk culture even more widespread, until punk could get to the international scene. With its independence punk was able to hold a concert independently (Al Ramadhan, 2016). At present, young people with different dress styles and unique lifestyles can generally be found in various cities in Indonesia. These punk kids not only work but they also often hold banquets together (parties, music performances, and drinking). Usually on Sundays it is often used as a time to gather by them and hold joint actions, and in the event there will usually be various streams from the community itself demonstrating their respective abilities. On this occasion they dressed up as we would like to go to a shopping center which they called with ngedress (using their complete attributes without lacking anything).

Seeing from its history Punk is actually a cultural community that emphasizes more on a free life, punk was originally a music community that brought trush metal flow. In the world of punk there are various types of punk that carry different ideologies, as explained by Mukhlis (2018), including:

a. Anarcho Punk is one community that is very hard and idealistic with the ideology they profess. They close themselves with others and violence has become a part of themselves, they often clash with their fellow communities.

b. Crust Punk is famous for its shriveled appearance and its criticism is very spicy, they choose to live wandering and migrating

c. Glam Punk members of this community are artists whose daily experiences are expressed in their own work. They are opposed to disputes.

d. Nazi Punk is the smallest minority in the punk subculture. Its members are of the ideology of white nationalist ideology which is closely related to white skinheads. e. The Oi they usually sleep on the streets of busking, they are hardworking. but often cause trouble

f. Querrcore members consist of people who are generally sick, namely lesbians, homosexuals, and bisexuals.

g. Riot grrrl often raised issues about rape, domestic violence, sexuality, and empowering women.

h. Scum punk they are very concerned with comfort, cleanliness, moral goodness, health, and respect for themselves, as well as others. They try to stay away from dangerous drugs like drugs.

i. Skate punk members like to skate board

j. Ska punk is a combination of jamaika or reggae music

After knowing what is punk, its history, ideologies, types of punk, then what needs to be known is what factors cause a person to enter the punk community. These factors include internal factors. These internal factors can be in the form of the need for freedom, then the need for existence. In addition to internal factors, there are also external factors that cause them to join the punk community, which include disharmony between families, being influenced by friends, teenagers' interest in the punk community, needing a lot of friends, and a lack of economics for the lower classes.

In the perception of the punk community is always considered negative, criminal and ringleader, this happens because the appearance of punk children who are not normal and different from the general public, punk dress up with mohak hair, tangled clothes, seem untidy, and also dirty. Punk kids from the lower classes who often sing and sleep on the streets are often seen poorly by the public because they sometimes steal food at the warungs when they are starving.

\section{Method}

This research focuses on the symptoms that occur in society, the factors that influence the phenomenon of the focus of discussion and sociocultural phenomena in certain communities. In this study the authors used a sociological juridical research approach. The problem that is the subject of this research is to remember to relate and relate social factors to juridical factors. 
Soerdjono Soekanto (1986) and Arifin et.al. (2018) states that the sociological juridical approach is to identify and conceptualize law as a real and functional social institution in a real living system. This sociological juridical approach is based on the problems that occur in society, both actions taken by humans in the community and the implementation of law by social institutions (Sunggono, 2006; Arifin, Waspiah, \& Latifiani, 2018).

The phenomenon of actions and behavior carried out by members of the punk community who have been labeled criminal acts by people who feel they have been troubled by all forms of actions they take. The formation of this punk community is actually a form of protest and expresses criticism and opinions towards the authorities. By using this method of sociological juridical approach, it will be able to examine more deeply what are the causes of bad behavior from the punk community, forms of punk children's actions, how to deal with and cope with these actions, as well as finding the best solutions for crime from the punk community. can be resolved based not only in terms of the prevailing positive and juridical norms but also in terms of norms that live in people's daily lives.

This research was conducted by a team of writers in 2 places, in the Ngaliyan area, Semarang City and in the East Kriyan Village, Cirebon. Precisely at 1). Jl. Ngaliyan 234, Ngaliyan, Kec. Ngaliyan, Semarang City, 2). Jl. Prof. Hamka, Tambakaji, Kec. Ngaliyan, Kota Semarang, 3). Kampung Kriyan Timur, RT 02/16, Cirebon. In several locations in Ngaliyan, Semarang City and surrounding areas, punk punk groups are often found. But their existence is not permanent but nomadic or nomadic. So this research was conducted by adjusting the place / location of one or several members of the punk community. The author feels that this is in accordance with the focus of research that focuses on the causes and forms of criminology carried out by punk children or the punk community.

The location that the author chose is a location that is often encountered and a gathering place for punk kids. Indirectly, people can not see and distinguish whether a person is a punk or not because people often assume that the street children they meet on the street are also part of punk kids. In addition to taking action punk children always take actions that are always assumed negatively by the public, they also do some positive things that are not widely known by the general public. The writing team felt the facts behind the good actions and the bad domination of punk menark to be used as research.

\section{Result and Discussion}

\section{A. Definition of Punk Community}

Community is a collection of various populations that live at a certain time and area that interact with and influence one another. Communities have a more complex degree of cohesiveness when compared to individuals and populations. The formation process is horizontal because it is carried out by individuals of equal position (Alfiansyah, 2017).

The Indonesian Wikipedia explains the notion of community as a social group of several organisms that share the environment, generally having the same interests and habitats. In the human community, the individuals within it can have intentions, beliefs, resources, preferences, needs, risks and a number of other similar conditions. Community is a group of people who care about each other more than they should, where in a community there is a close personal relationship between the members of the community because of the similarity of interests or values.

Punk children is a movement of a group of young people who experience economic and family problems, and freedom to inspire, expressions with different styles. Punk seeks to insinuate entrepreneurs in their own ways, through songs with music and lyrics that are simple but sometimes rude and jerky.

The life of a punk who is often found can be concluded that there is no age restriction in the world of punk. The characteristics of punk children as explained by Haryanto (2019) are as follows:

1) Being in a public place (streets, markets, shops, entertainment places)

2) Good looks (standing hair or Mohawk, wearing earrings, chains, boots, tight jeans and shabby clothes, leather jackets).

3) Derived from families who are not harmonious and unable

4) Doing activities as a punk.

Although common characteristics are known, it does not mean that punk children are a messy youth, rubbish to society. In their lives they still have diversity due to differences in family 
backgrounds, length of stay in the streets, neighborhood, occupational choices, relationships and even income patterns.

In carrying out his life punk can be used as an ideology, lifestyle and as a genre of music. Punk as an ideology underlies the ideology of anarchism. Secare etymology, anarchism is the basic word of anarchy which ends with ism.

Punk as a lifestyle is more famous than the fashion worn and the behavior they display, such as Indian tribal mohawk haircuts, or cut and colored with bright colors, boots, chains and spikes, body piercing, leather jackets, pants tight jeans and worn clothes. Such appearances are very prominent in this community and are characteristic of punk kids. This unusual outfit also causes a negative public stigma against punk kids.

Lifestyle is the result of one's interpretation of the environment from an early age, the formation of lifestyles is obtained by children from experience, if the style has been formed, the child's response to new situations will be determined by that unique lifestyle. The way to do is his lifestyle.

Punk as a genre of music is a grouping of music according to their similarities with each other. A genre can be defined by music technique, style, context, and theme of music. Punk is one of the genre of loud music. Overall streams in this rock, including Classics Rock, Progressive rock, alternative rock, hard rock, punk rock, heavy metal, speed metal, thrash metal, grindcore, death metal, black metal, gothic, and doom (Alfiansyah, 2017).

Punk music actually does not appear solely because of the boredom of young people towards the concept of music that has come first, the essence of punk is not just a tone revolution. It can be said that punk is a community of antitrust musicians, therefore in principle their position is opposite to industry circles. Music punk people are more driven by a number of things that clump in the bottom of their souls, whether the outcome will be liked or not. But one thing that will not change is the essence of the spirit of punk as a suggestion of rejection of the values of establishment.

Music is one of the punkers' self-expressions, which is lived up to the mood, so it's no wonder that there is an element of violence not only on pogo or on the music, but also on lifestyle. In this type of song will be found several symbols that indicate the strength and choice of the ideology of the singer or singer group.

Actually they are people who are anxious to find solutions to destroy the tyrants. Then the unrest they manifested by rebellion with various forms both through music, propaganda, and making their own products. Basically they want to be able to create their own currents. Thus the punk child has a purpose in life in his own way and the target is familiar and must have a strategy in realizing all the will of the punk child.

Punk as a form of expression of rebellion and social protests before, punk as a new container for the outburst of dissatisfaction from young people who deprive their rights. This dissatisfaction is not only dominated by culture, but with what is observed as a sense of community with failed forms of rebellion. The essence of punk is the spirit of anti-adjustment from resistance to the government and facing the government and the rejection of the most legitimate authority. Then punk can be a social space and a place of self-disclosure for young people who are dissatisfied and become a source of political protest and criticism.

Punk communities can be categorized as informal social groups. The informal group has no official status and is not supported by written statutes and bylaws, has a division of tasks, certain hierarchical roles. As well as the norms of the behavior guidelines of its members.

\section{B. Description of the Life of a Punk Community}

In general, punk's daily life is hanging out, busking to buy food together and participating in special punk events. Factors for punk children can be classified into two (Haryanto, 2017), namely:

\section{1) Internal factors}

a) Lazy nature and do not want to work

b) The dream of freedom. Sharing problems faced in the family that can cause rebellion in him and try to find a way out. A child feels bored and tortured at home because every day watching his parents fight and not paying attention to them, in the end he chose to be a punk because they have many friends who can accommodate their complaints.

\section{2) External Factors}

a) Influence of friends. The influence of friends is one factor that causes them to be punk kids. The influence of friends becomes a big impact.

a) Violence in the family. Violence in many families was revealed as one of the factors that drove them to run away from home and become punk kids.

b) Thought of punk kids. Thought punk children most of them want a pattern of free 
life of expression without following the rules of the family or from the state or government that restrains itself. So they decided to fight by becoming or following one member of punk.

\section{Public's View of Punk Community}

The public's view of the punk community in terms of their style of makeup, quite disturbing comfort, various negative meanings are often applied to punkers. Usually their characteristics can be seen from the clothes used, such as boots, haircuts and colored with bright colors, wearing chains, leather jackets, tight jeans and worn shirts. One's behavior is influenced by symbols given by others, so the symbols given by the community to the punk community are symbols of discomfort, discomfort and unrest.

The existence of the punk community is still considered a social problem in society. The appearance of an identical punk is considered a social problem in society. Appearance of punk kids who are identical with black clothes and dirty looking makes people see them as uncomplicated. Gathering at crossroads and doing activities like street children like busking, for some people is something that damages views. In addition to negative reactions, people also react apathetic or indifferent to punk children.

The phenomenon of punk kids who are considered as one of the social ills needs to be minimized. In this case, it needs to be straightened out in a better direction by prevention, not by anarchist or violent means. Basically, they are an intelligent community and have the creativity that must be developed.

When viewed from the perception of society, the phenomenon of children is an abnormal thing. This phenomenon is something that is not feasible for people who are educated, because the behavior and attitudes of punk children are not in accordance with existing norms. Besides punk does not have extensive knowledge, skills that are not channeled, not independent, irresponsible, not easy to adapt to new people and lack of benefits to others.

\section{Criminology Theories concerning to the Case}

Theory functions as a tool to facilitate and understand a problem. In this paper explains several theories that can be used to understand the problems of punk kids. However, there are many other criminological theories that can be used and cannot be explained in this paper. Almost every theory has different characteristics in understanding society because the originator has a paradigm that is not always the same. However, because theory is a tool the truth of the contents of a theory can still be debated, refuted, quarreled, and possibly refined based on the latest research results. Some theories used in the discussion of this paper are as follows:

\section{1) Anomie theory}

The theory of anomy was put forward by the French sociologist Emile Durkheim and Robert Merton. Durkheim's opinion was put forward earlier than merthon. Durkheim uses the term anomi to refer to a condition that is experiencing de-regulation (Hardianto \& Qamar, 2018). According to him, rapid and tense social change in society has a great influence on all groups and communities. The main values and values that have been accepted by the community are blurred and even disappear. These conditions encourage the uncertainty of norms and even the absence of norms.

The state of deregulation is defined as a condition where non-observance of the rules that exist in society, and community members do not know about what is expected by others. This situation is considered as the cause of deviant behavior.

Robert Merton further revealed that deviant behavior is considered as an abnormal behavior because the behavior originates in individuals (Hardianto \& Qamar, 2018). Deviant behavior arises because there are a number of people who feel the gap between the ideals owned by the means available to achieve these goals (Hardianto \& Qamar, 2018).

In every practice, not everyone can use the available means to achieve goals. Because of this, many people impose their will to achieve their goals, even though the method used is against the law. The way to achieve goals that violate this is called crime. The discrepancy between the facts and the delusion results in tension and frustration which in turn will cause a psycho-physical response to the individual and ends with violence or resistance. People who suddenly get more wealth than they ever dreamed have a tendency to believe that nothing is impossible.

According to Emile, anomic theory consists of three perspectives, namely:

a. Humans are social creatures

b. The existence of humans as social creatures 
c. Humans tend to live in society and their very existence depends on the community as a colony.

2) Theory of Social Control

John Hagan asserted that social control theory departs from the assumption that every individual in society has an equal chance of becoming someone who violates the law or obeys the law. The social control theory poses a fundamental question as to why not everyone violates the law or why there are people who obey the law (Hardianto \& Qamar, 2018). According to social control theory, humans have the freedom to act, and the determinant of a person's behavior is social bonds that have formed. These social ties are interrelated between one community and another.

The behavior of a person who is good or bad depends entirely on the surrounding community. Everyone who is weak or even broken with social ties will tend to do bad behavior. This also happens if the social control institution experiences a decline in authority, both formal and informal control institutions. Statutory regulations made by the state in writing that function to regulate people's lives, are called formal control institutions. Informal social control institutions include unwritten laws whose validity is recognized by the community. However, informal means of control are sometimes more binding than means of control in the form of written law. This theory is too see that humans and every human can do evil if given the opportunity.

3) Labeling theory

Labeling is a definition that when given to someone will be the identity of that person and describes people with what type he is. By labeling someone, we tend to see him as a whole person, and not in his behavior one by one.

The nickname theory simply states only two things. First, people behave normally or not normally, deviate or not deviate, depending on how other people judge it. That judgment is determined by the categorization that is already attached to the thoughts of others. Everything that is considered not included in the categories that are considered standard by the community, will automatically be said to deviate.

Second, that assessment changes from time to time, so that people who say today are declared sick can be declared healthy (with the same symptoms) a few years later or vice versa. When someone gets a nickname that leads to crime or criminal behavior, then that person can be vigilant to see their negative side (for example people who are given the nickname naughty, criminal, etc.). Labeling theory focuses more on understanding juvenile delinquency because this happens all the time when adolescents try to shape their identities.

In principle, social designation is formed by systematization (Ahmadi \& Nur, 2005), as follows:

1) People can be seen in behaviors that are at risk of being labeled as perversion, delinquency, or crime

2) There are two types of behavioral deviations

Primary deviance, which assumes that everyone has the same opportunity to violate social norms and regulations with or without clear reasons.

Secondary deviance, i.e. after deviant behavior is carried out and labeled as a trouble maker or problem maker, then this nickname will stick and direct it to make more deviations (this is the focus of dubbing theory)

3) Secondary devience is formed after the community / social care and be careful of the behavior of the first deviation

4) Only after the nickname is attached does the movement of criminal behavior actually increase.

The nickname theory is important, because this theory departs from the assumption that no action is intrinsically criminal. The definition of crime is determined by the ruling party, through the formulation of law and interpretation by the police, the court, and penal institutions. According to this theory, the labeling process is so powerful that victims of this mistaken definition cannot withstand its influence. Although, at first it was against their will. The impact of this nickname is more severe, especially for people who are in a weak position. In other words, this theory states that how self-identity and behavior are influenced or created by social systems.

In sociology and criminology, this theory focuses on linguistic tendencies which the majority have a negative label rather than the actual state or like a deviation from the norm and this is related to self-concept. In a sociological view, labeling relates to someone who is then labeled as having little chance of confirming the true meaning of the assessment (Ahmadi \& Nur, 2005).

In summary, John Hamlin states that the basic assumptions of dub theory (Ahmadi \& Nur, 2005), can be written as follows:

1) It is the application of the symbolic interaction theory of George Herbert Mead that focuses on deviant behavior and the processes of social 
audiences that create deviations and deviations (deviant people) which cause it to behave as labeled by the community.

2) Is a process of transfer and take place between behavior and actors, labels are easily transferred from one to another

3) Labels relate to how norms and behavior are formed, but the relationship is broken easily

4) Is a theory that changes a person's identity, by changing his primary behavior into secondary behavior

5) Not everyone getting a label will have the same impact. Some people might like it, but others don't.

6) There are dangerous consequences for abduction victims

7) Nickname theory does not specify what nickname is given first, but how it survives with the nickname given.

According to Becker and Lemert, there are four basic elements of nickname (Ahmadi \& Nur, 2005), namely:

1) Social labels are given on certain behaviors

Social conditions create norms and rules that require every individual to follow them, and if they do not follow it will be defined as abnormal behavior.

2) Crime is mostly caused by social regulations When regulations are considered as something that must be obeyed, it will depend on the moral significance of the community. For example, free sex.

3) Social control exacerbates criminal problems

4) The existence of interconnected power between people who are given the nickname given.

Nickname theory sees that sometimes humans are helpless victims of interpretations or labels given by others in such a way that their social identity can be forced upon them even if it is against their will. Observations or cases of exconvicts in our country show that the nickname given by the community to the former resulted in some of the ex-convicts internalizing the nickname so that it became part of their self-image and awareness.

\section{E. Punk in Indonesia and Criminological Actions}

In the history of punk kids in Indonesia and related to criminal acts by punk kids, we got information from UIN Semarang students who are still active with their punk community. According to the SQ guest speaker UIN Walisongo smarang who is still active in the punk community, he believes that "in the country where punk was born, Britain, Punk was a form of British youth's disappointment with the political situation and conditions in the 1970s. They come from working class youths, such as workers who feel disappointed with the moral decline of the government and the mainstream cultural community and also the prolonged economic slump. but when punk enters the State of Indonesia it is misunderstood and the punk community in Indonesia is not in accordance with the principles of punk. One of the principles of punk is DIY (Do It Yourself) or be yourself, "

The rejection that they often experience because of their lifestyles and mindset that is considered unusual by the mainstream groups finally punker made their own ethics of living, namely DIY (Do-ItYourself). DIY emphasized that punker does not need anyone to be able to survive. But Punk ideology quickly spread by using DIY ethics. Punker spreads his ideology and ideas including music and fashion.

Moore and Roberts's study was carried out using a historical-comparative methodology with primary and secondary sources including ethnographic data and other archival material from other studies of the punk subculture. The Moore and Roberts Study examined three different cases in which the DIY subculture was involved in the political agenda at the time: Rock Against Racism, the "hardcore" movement, and "riot grrrl". Once the bastards stick to political agendas they use DIY ethics to enhance subcultural relations ideally. Rock Against Racism is a movement where bastards discuss the idea of anti-racism, while the "hardcore" movement is a rebellion against President Reagan's actions. The "riot grrrl" movement is a way for women to create networks with other individuals who share their feminism beliefs. In their analysis, Moore and Roberts discuss how the punk subculture as a whole is shaped by music and general similarities. individual larity involved. Once punk decides to voice their political views, they look to DIY ethics to share their views with other punks. They may publish their political views on fanzines that are distributed to other punk collectives. The global network involved in sub-structuralism depends on each other to support tour bands who travel to play scenes around the world.

The birth of the punk community in terms of criminology occurred in accordance with Anomi's theory. According to Robert T Merton, the 
anomie theory initially described the delinquency behavior with certain stages in the social structure that would give rise to, give birth to and grow a condition against a violation of community norms which was a normal reaction. For this reason, there are two elements underlying the formation of punk in terms of social and cultural structure. Concretely, the element of culture gave birth to goals and the structural element gave birth to means. Goals are defined as human goals and means are defined as rules and ways of control that are institutionalized and accepted as a means of achieving goals.

According to SQ, punk and criminal have to divide punk children into 3 categories from an economic perspective. (1) First is lower class punk, second is middle class punk and third is upper class punk. Lower-class punks who are less economic than having to take to the streets to make a living. They joined our community because initially from the problem of broken home, looking for freedom and some who just wanted to play. (2) Furthermore, the middle class, namely people who enter punk because they are depressed by the rules of their parents until they want to seek freedom and enter punk. And there they felt many things when they joined punk. (3) And finally the upper class punk is a collection of punk kids who are economically rich. perhaps the majority of people who belonged but lacked affection from parents and finally sought refuge in the punk community. And related to SQ crime revealed that not all who commit crimes are punk. But in reality, there are many media that label that punk is the culprit while we have our own principles and punk's aim to fight against government injustice. But it cannot be denied that punk children from the lower classes committed criminal acts because of economic pressure. It must be stressed that punk children have their own goals and principles to eradicate the injustice of the government. There is resistance because of injustice. the formation of punk culture as a counter-culture is based on 4 main elements; music, fashion, community and thought; the spread of punk culture in Indonesia through the four elements. And that's the way punk kids put up a fight against the government. It should be underlined that actually punk children are not all economically poor, but the majority of punk children are victims of government discretion. And the fight arose until finally causing a criminal act because of some pressure.

Why do punk kids commit crimes? In the past, punk kids shrieked in dressing because they used principles only because they were against the government through songs (metal, punk reggae, etc.). before it can still be distinguished punk kids or not. And if now it's hard to tell which real punk kid isn't. In fact, according to the media, punk children commit crimes, but those who do are not punks, but every mistake is seen by punks who commit them. In terms of idealism, punk children are superior to others, and now our resistance is through resistance music. And we can be sure that today there are many who are not pure punk because they have been contaminated with others who are not real pure punk and who triggered criminality because punk is considered inferior in terms of humanity. down on the streets. And the fading of the principles of punk kids is also what we can call the things that trigger crime against punk community.

SQ added that related to the case of an unjust government, punk children used the principle of nihilism which means they did not believe in injustice, which means that when there is injustice, a resistance is born. Punk talks about freedom, selfcontrol without norms that ensnare, many people who think that punk children are none other than thugs, drunkards, trash for the community and so on but they are wrong punk has its own community that is anti-oppression, anti-restraint and antiestablishment but there are also many kids who claim to be punk without knowing what punk really means. Punk is not just music, not just fashion but punk is a lifestyle that has its own idealism. Punk's journey is not without purpose, with its existence proven to be small but still meaningful. Although it is known that there are general characteristics, it does not mean that punk children are sloppy young people, rubbish to the community. In their lives they still have diversity because of differences in family backgrounds, length of time in the streets, neighborhood, choices, jobs, relationships and parenting patterns.

Factors underlying today's young people follow the flow of punk, among others, the environment and conditions of family residence much influence on the problem of delinquency so that children often skip school. Then the social and economic conditions of parents also influence, for example those in the poverty line and the inability of parents to establish good ties with their children (Haryanto, 2012).

Children become punk children who take to the streets in addition to looking for freedom, hanging out, the influence of friends, seeking calm 
due to violence in the family, frustration in their lives and to meet daily needs such as eating, sleeping and looking for shelter. They decided to live on the road to avoid problems, but from the observation data collection in Ngaliyan it is not uncommon on the road that they sometimes get bigger problems. The figure of punk kids popping up in the city, be it in the storefronts, at the station, terminal, market, roadside, tourist attractions.

Punk fashion is a manifestation of their motto. They express themselves in a way that is extraordinary different from the others. Their appearance is far more shocking and frighten people around them. Identical to their style with inappropriate objects such as pins, plastic clothes clips, television components, razors, tampons that are the usual accessories for punk kids and sometimes they even smear blood on brand T-shirts and their hair dyed with spike style, Mohawk, bihawk and quarter.

The reason punk has their own fashion to represent resistance to the upper (middle) class. In communicating the resistance, punk children use attributes that conflict with those of the upper classes. For example the use of boots that represent the workers; high-value metal-based accessories differ from high-grade metal-based accessories; tight and torn jeans as a form of rebellion against the bourgeois dapper style; and spike and mowhak haircuts imitating the hairstyles of ancient Indian Mohican tribes as a representation of resistance to dominant power (Haryanto, 2012), in this case entering into the labeling theory which explains why and how certain people are given a distinctive stamp or label, giving influence as a consequence of a perversion of behavior. Labeling theory is related to the style or fashion of punk as their label and applies aspects of labeling theory that people become criminals not because they break the law but because it is determined by the ruling authority.

\section{F. Crimes Committed by Punk Community}

Crime and crime have become its own social problems for almost the entire world community. Moreover, at this time the rampant cases of crime that occurred where the culprit is a child. the development of the crime lately not a few children involved in crime. Lately we often see and hear the mass media incessantly preaching various kinds of crimes committed by children.

In Indonesia, there are several types of child crime that are associated with parents' negligence in conducting care. If negligence is found, then the parent will take responsibility for the crime committed by the child in a criminal way. According to Caspi and Molfit's research (2001 in Davies, Hollin and Bull, 2004) the behavior of child crime from small crimes such as stealing to serious crimes such as murder has emerged from childhood but will reach its peak in adolescence, namely vulnerable age 16-18 years . The United States Department of Justice in 2006 also found that around 10 percent of the killings occurred were committed by juvenile offenders (Ihsan, 2016).

The life of a punk is known to be hard and full of various exploits. We can liken a punk child like a human figure like a wolf who always preys on other humans easily found in street life. The streets are like wilderness that enforces the law of the jungle, who is strong he will be the winner. So, when children, especially punk children who in normal life are still marginalized, right enter the world of punk. Punk community is one community that is very tasteful. Bad experiences that are often heard have been experienced, making punk children are required to connect their creativity which is not only getting money to finance his life but also in an effort to protect himself from various threats that exist. When the danger is threatening, any action will be lawful for him.

From the information from the initials AL, who is domiciled in Jakarta and migrated to Semarang due to a big fight between parents and children. From the information of a guest who lives and makes a living on the road explains that the occurrence of criminal acts committed by children on the street due to economic pressure. Criminal acts committed such as begging, stabbing and theft or pickpocketing. What is meant by economic pressure is when a psychic situation forces to commit criminal acts and the coffers of money generated by the job of guarding parking are insufficient as a result turn to things that hurt others and lead to murder. The action was not carried out as often as possible, only done when the circumstances were urgent and together with his friends. The majority of those who go down the street do not have a house for shelter (nomadic)

Not only criminal acts committed. The violations committed with his friends such as Dosping namely taking illegal drugs that should not be intended for human consumption without doctor's advice, and also drink containing alcohol. As a result of the influence of alcohol can trigger fights with his opponent. This is very dangerous can take lives. 
Street life turns out to be not as bad as one might imagine, among a group of punk kids often identified with liquor, drugs, free sex. There is still a speck of light that gives hope that propaganda among those who are considered marginalized is still there and might be done. Sometimes they feel they do not have God as their creator because they do not want their lives to be regulated, there are also those who feel that they still have God even though sometimes they have never done any obligation as a Muslim. Those punk kids still believe in God as the creator and still feel religious even though the punk kids perform their duties like prayer only sometimes because everyone has their own character and personality.

Besides the criminal acts of punk children, there are also actions to show the concern of punk children towards social inequalities that occur in society. One example in Semarang is the punk community which established the Satriots Community with the Muslim Punk label as an effort to improve human resources in the community. The life of a punk who is known by the community as a community that doesn't care about people's lives is not as bad as imagined. The public's view of punk community is still bad.

So powerful in declaring violence in the Criminal Code one of which is street crime such as theft, extortion, rape, torture, acts of violence against people or goods, drunk behavior in public, which certainly can disturb public order and cause unrest in community (Fadlina, 2014).

According to the informant, he admitted that committing a crime was due to economic pressure and was spiked with revenge for words with his friend plus the influence of alcohol and drugs. He added that during the crime he did not take casualties. The average punk kid who committed a crime with him ranged from 13-20 years. The motive for joining a punk child is to look for attention to the imbalance that occurs between parent and child. Those who commit crimes are one of the victims of criminal acts in their area, the factor triggers the birth of the evil nature that exists in children. Criminologically based on sociological crime is a pattern of behavior that is detrimental to society or in other words there are victims and a pattern of behavior that gets social reactions from the community. These social reactions can be formal, informal, and non-formal reactions.

One of the most troubling forms of crime is theft. Imagine, this type of crime when viewed in terms of quantity is the type of crime that is most often encountered. If viewed in terms of quality, theft has increased in quality. This can be seen from the variations in the mode carried out by the thieves. Variation of theft developed with the times and technology. The perpetrators are good at utilizing technological sophistication even though there are still perpetrators of theft who use the conventional mode to launch the action. As it is known in crime cases there are always victims, where the victims are those who have suffered physical or psychological losses, property, and life salvation. The most common thing is that the victim feels trauma and fear after experiencing a crime where this greatly affects his psychological condition. Not a few also the victims took their revenge by following the perpetrators' behavior. In accordance with the acknowledgment from the AL sources that those who committed a criminal act were those from criminal victims.

The trauma, worry and fear experienced by victims of crime are a common psychological impact. This certainly greatly affects the welfare of life or well-being victims. Well-being can refer to many meanings such as pleasure, life satisfaction, positive emotions, meaningful life or feeling meaningfulness (Wildani, 2014). According to Ryan and Deci (in Wildani, 2014) there are two approaches in explaining well-being, psychological and subjective. Where the psychological concept of viewing well-being is not only as pleasure, but also the realization of the potential of an individual in identifying who he really is while the subjective concept of looking at well-being is composed of subjective happiness and focusing on the individual's experience. Where the concept of subjective well-being emphasizes more pleasant and unpleasant experiences obtained from an individual's assessment of the experiences that occur in his life (Wildani, 2014; Nathania, 2017).

In Indonesia, there are several laws and regulations governing children, for example Law No. 11 of 2012 concerning the Criminal Justice System for Children, Law Number 4 concerning Child Welfare, Law Number 39 of 1999 concerning Human Rights, Law Number 23 of 2002 concerning Child Protection and various other regulations relating to the problem of children ( Ihsan, 2016).

The definition of a child based on Article 1 point 1 of Law Number 23 of 2002 concerning Child Protection is: "A child is someone who is not yet 18 (eighteen) years old, including children who are still in the womb." While based on Article 1 
paragraph (3) of Law no. 11 of 2012 concerning the Juvenile Criminal Justice System also describes children in conflict with the law, namely: "Children in conflict with the Law, hereinafter referred to as Children, are children who are 12 (twelve) years old, but not yet 18 (eighteen) years old who is suspected of committing a crime."

The next criminal offense committed by punk children from the lower to middle class phenomena of begal or robbery in the street and become very popular in the community. Citizens are troubled by the actions of gang members accompanied by violence and sharp weapons. This action became a frightening specter on the streets for all Indonesian people. Not only occurs in the suburbs, but this phenomenon is like snowfall, becoming an acute phenomenon that has been troubling people in various regions in Indonesia. Starting from Sabang to Merauke. Today's adolescent behavior is increasingly contrary to the norms prevailing in Indonesia. With the rapid development of technology, followed by a lot of misuse of the technology for negative things. According to the SQ informant, this is not in accordance with the principle of punk children who stand for injustice committed by the government. But because of the lack of work and the high necessities of life the way a criminal action becomes the most effective solution. From the point of view of Anomie's theory, namely having desires to be fulfilled their needs so as to justify all means to carry out all actions with a record that their needs are met. Anarchist begal groups are social structures formed informally created by communication between members.

\section{G. Factors underlying the Criminological Actions of Punk Community}

According to the resource person with the initials AT the factors behind the occurrence of criminal acts committed by the lower middle-class punk community namely: The influence of drugs and alcohol, High unemployment. Perpetrators of crime victims. Theories of crime according to Nature (in Sohopi, 2014) there are several theories underlying the occurrence of crime.

First, labeling theory. Give a label or stamp to someone who often commits a crime as a result of the community's reaction to the action taken. Second, cultural deviance theories (cultural deviance theories). This theory of cultural deviation focuses on the social forces that cause people to carry out criminal activities. Cultural deviance theories are further divided into two, namely social disorganization theory which focuses on the development of areas with high crime rates and is associated with the disintegration of conventional values caused by rapid industrialization, increased immigration, and urbanization and different association theories which are individual approach to a person in the life of his community, because his experiences grow into villains These individuals or groups of individuals are sure and conscious of doing unlawful acts. With the reduced sense of solidarity of citizens living in urban areas and the still many cases of crime that occurred in Jakarta shows that there are factors of cultural deviation, namely social disorganization theory. Crimes occur due to changes in values due to the rapid industrialization process

Third, economic factor theory. A low economy tends to make individuals commit crimes (Sohopi, 2014). According to the first subject the economic level of urban society is more difficult to find work especially, to make a living

"We are very difficult here to get a job, just working as a parker is already grateful than not at all. We are doing things that are clearly violating the law because we are forced to because of guarding this parking is not enough to make a living."

According to SQ sources, today's criminal acts committed by punk children are not a reflection of the noble principles of punk, but a contraction from the influence of other communities. In answering: why a child commits a crime, what is found is not a single factor but several factors which together cause child crime, both internal and external factors. In the internal context, what influences a child's crime is personality, self-concept, social adjustment, developmental tasks and low problem-solving ability. While external factors are how the family environment such as parenting, school environment and peer environment affect children. According to Tutus Kusniyah the factors behind the occurrence of criminal acts:

\section{A. Internal Factors}

When discussing the problem of delinquency or criminal actions committed by children, the thing to know is what is the background or factors that cause children to commit criminal acts. Internal factors that influence delinquency behavior by children, are aspects of personality that originate from within the child such 
as low self-concept (Yulianto, 2009), social adjustment and low problem solving abilities, excessive attitudes and low self-control. The concept of self is how individuals perceive themselves including physical aspects and psychological aspects. The physical aspect is how the individual views his body condition and appearance. While the psychological aspect is how the individual views his abilities, self-esteem and self-confidence of the individual.

In this condition, the psychological condition of children during adolescence has characteristics that are unstable, difficult to control, fight and rebel, have a high curiosity, are aggressive, are easily aroused and have high loyalty. As explained above, that the first environment of a child is a family environment, when stepping on adolescence, the child begins to recognize and interact with the environment other than the family environment. In this situation, children tend to compare conditions in the family environment, the school environment, the environment of their peers or even the social environment in which each of these environments has different conditions. Differences in various environmental conditions cause adolescents to experience confusion and find out and try to adapt to be accepted by the community (Sarwono, 2013). At the time of experiencing the multiple conditions, adolescent psychological conditions are still unstable, so that it can lead to delinquency and criminal behavior committed by adolescents.

\section{B. External Factors}

The big external factor influencing children with crime is the family in this case the condition of the family environment. The condition of the family environment during the development of children and adolescents has long been considered to have a relationship with the emergence of antisocial behavior and crime committed by adolescents. Several studies on the development of delinquency and criminality in adolescents, found that crime is caused by the experience of poor parenting. The third pattern of parenting for children, namely authoritarian, permissive and univolved parenting causes a child to behave anti socially.

When children experience poor, abusive, neglected care and there is violence in the family when the child is in the early development of children, then the child will have low self-esteem, will also develop such violent behavior in siblings and also develop antisocial behavior. Then when children start entering the school environment, children with low self-esteem will get isolation from their peers and experience difficulties in school, play truant, and experience failure in academic activities at school. The children then develop into adolescents who have a tendency to associate in gangs, and deviant peer groups, as well as self-direction in violence, because they think that peers can accept their conditions.

As they grow older, they will continue violent behavior, acceptance and violence in personal relationships, and continue in the cycle of violence when they get married and adopt a parenting style that contains elements of violence on their children. So that their children will develop into individuals who commit delinquency and criminal acts. This is similar to research that shows that aggressive behavior or aggression has a genetic contribution or is inherited by parents in their children, especially in antisocial behavior. Poor family relationships between parents and children are also genetic or inherited. The mechanism of development of antisocial behavior above is in the form of a cycle, so that acts of violence or improper care by parents will form a chain of development cycles that cause children to commit violent behavior or even criminal acts.

\section{Conclusion}

This research concludes that crime itself means an action that violates the legal norms (criminal law), harmful behavior, behavior that causes victims. according to criminology in Indonesia, crime is seen as behavior that has been decided by the court, behavior that needs to be criminalized, population of detained perpetrators, acts that violate the norms, actions that get social reactions. The crime committed by punk children is caused by various factors, especially from family, education and economic factors. For the family itself, it is best to educate children as well as possible so as not to break the home destroying the child's future. Government institutions should provide wider employment opportunities for small communities so as to reduce the risk of criminal activities committed by the community. And for people, don't always judge and label someone bad from their appearance because what was good can turn bad because of labeling. 


\section{Declaration of Conflicting Interests}

The authors state that there is no potential conflict of interest in the research, authorship, and/or publication/publication of this article

\section{Funding}

None

\section{References}

Amiruddin dan Zainal Asikin (2004). Pengantar Metode Penelitian Hukum. Jakarta, Indonesia. PT. Raja Grafindo Persada.

Bambang, Sunggono (2006). Pengantar Metode Penelitian Hukum. Jakarta. Rajawali Press.

Lexy J, Meleong (2013). Metode Penelitian Kualitatif. Bandung. Indonesia. PT Remaja Rosdakarya.

Moeljatno (1999). Asas- asas Hukum Pidana Edisi Revisi. Jakarta. Rineka Cipta.

Moeljatno (2011). Kitab Undang - Undang Hukum Pidana. Jakarta. PT Bumi Aksara.

Ronny, Soemitro, Hanitijo (1990). Metode Penelitian Hukum dan Jurimetri. Jakarta, Indonesia. Ghalian Indonesia

Soekanto, Soerdjono (1986). Pengantar Penelitian Hukum. Jakarta, Indonesia. Penerbit Universitas Indonesia Press.

Utari, Indah Sri (2012), Aliran dan Teori kriminologi, Thafa Media, Semarang 2012

Suharsimi, Arikunto, (1999). Prodesur Penelitian: Suatu Pendekatan Praktek. Yogyakarta, Indonesia. Rineka Cipta.

Lan P. Moran (2010). Punk: The Do it Yourself, Social science journal, Vil. 10

Western Connecticut State University.

Thompson, Punk Productions, Unifhinised Busines.

Trumbull, M \& Watson, K (2010). Qualitative Research Method. Integrating
Quantitative and Qualitative Methods in Research, $3^{\text {rd }}$ Ed.pp.62. USA. University Press of America, Inc.

Yin, R.K (2011). Qualitative Research from Start to Finish. The Guilford Press.

Fadlina (2014). Data Mining untuk Analisa Tingkat Kejahatan Jalanan dengan

Algoritma Association Rule Metode Apriori. Majalah IImiah 3(1): 144-154

Felicia Nathania," Analisis gambaran subjektif well being korban kejahatan pencurian dan penculikan, Jurnal Psikologi IImiah. Fakultas Psikologi Universitas Tarumanagara. 2017

Ihsan Khairul (2016). Faktor penyebab anak melakukan tindakan kriminal. JOM FISIP Vol. 3. No. 2

Mita Haryanto (2012). Profil Anak Punk 'Studi Kasus Di Pasar Gemolong" Universitas Muhammadiyah Surakarta. Nakah Publikasi.

Muhammad Fakhran Al Ramadhan. (2016). Punks Not Dead: Kajian Bentukan Baru Budaya Punk di Indonesia. jurnal makna, Vol. 1.

Mukhlis, Alma Yulianti (2018). Ketertarikan Remaja Terhadap Komunitas Punk, UIN

Sultan Syarif Kasim Riau.

Juliana, R., \& Arifin, R. (2019). Anak dan Kejahatan (Faktor Penyebab dan Perlindungan Hukum). Jurnal Selat, 6(2), 225-234. https://doi.org/10.31629/selat.v6i2.101 9

Arifin, R. (2020). Legal Reform Discourse in Indonesia and Global Context: How Does The Law Respond to Crime. Journal of Law and Legal Reform, 1(2), 193-196. https://doi.org/10.15294/jllr.v1i2.3705 7

Muhtada, D., \& Arifin, R. (2018). Introducing JILS 3(2), November 2018 Edition: Crimes and Society and its Contemporary Issues. JILS (Journal of Indonesian Legal Studies), 3(02), 147-148. https://doi.org/10.15294/jils.v3i02.276 04

Arifin, R., Waspiah, W., \& Latifiani, D. (2018). Penulisan Karya Ilmiah untuk 
Mahasiswa Hukum. Semarang: BPFH UNNES.

Undang Undang Nomor 23 Tahun 2002 tentang Perlindungan Anak.

Undang- Undang No. 11 Tahun 2012 tentang Sistem Peradilan Pidana Anak. www. Punk. Com.. diakses pada tanggal 10 Mei 2019.

Respository.uin.jkt.ac.id.diakses pada tanggal 10 mei 2019.

Uksw.education. Komunitas punk salatiga. Diakses 12 mei 2019.

Submitted December 9, 2019

Revision received January 12, 2019

Accepted January 25, 2019

Published online February 3, 2020

\section{How to cite?}

Millennia, N. I., Anan, Y., Lestari, I., Arifin, R., \& Hidayat, A. (2020). Punk Community in Criminology Study (Study in Ngaliyan District, Semarang City). Law Research Review Quarterly, 6(1), 47-60. https://doi.org/10.15294//rrq.v6i1.31232 
